DREW S. DAYS, III

\title{
Civil Rights in Canada: An American Perspective
}

\section{INTRODUCTION}

I would wager that far more Canadian lawyers have heard of Brown $v$. Board of Education ${ }^{1}$ than American lawyers have heard of Regina $v$. Drybones. ${ }^{2}$ Yet, the latter case occupies as important a place in the development of civil rights protections in Canada as Brown does in ours, albeit for a variety of different reasons. Moreover, probably few American lawyers know that Canada adopted a new Constitution in April $1982^{3}$ that contains the following provisions, among others: a guarantee to every individual of equal protection of the law without discrimination, particularly based on race, national or ethnic origin, color, religion, sex, age or mental or physical disability; explicit authorization for the creation of programs designed to ameliorate the conditions of disadvantaged individuals and groups, again with specific reference to those disadvantaged because of race, national or ethnic origin, color, religion, sex, age or mental or physical disability (affirmative action, in other words); a guarantee "equally to male and female persons" of the rights set out elsewhere in the Constitution (an Equal Rights Amendment); and an explicit grant to persons whose rights have been "infringed or denied" to seek court redress.

In truth, even those American lawyers engaged in full-time civil rights practices have rarely looked northward to discover how $\mathrm{Ca}$ nada was coping with its problems and, perhaps, gain some insights that might prove useful in addressing our own. This parochialism can be explained to a degree by the nature of legal education and practice in the United States. Although almost all American law schools provide courses in comparative law, such offerings are seldom regarded as being within the "core" curriculum. Hence, few

Drew S. DAys, III is Associate Professor of Law, Yale Law School. The author would like to thank his colleagues at Yale-Robert Cover, Mirjan Damaska, Thomas Emerson, W. Michael Reisman, Peter Schuck and Harry Wellington for their wise counsel, to Yale Law School for supporting his research, to John David Fraser of Dalhousie Law School for his invaluable guidance and to two librarians, Merle Fabian and Sheila Purse, of the Canadian Embassy and New York Consulate respectively, for their assistance.

1. 347 U.S. 483 (1954).

2. 9 D.L.R. 3d 473 (1970).

3. Canada Act 1982 (U.K.), ch. 11. 
American lawyers develop a comparative perspective on the law. In practice, consequently, neither lawyers nor judges feel comfortable introducing foreign law principles or authorities into the resolution of domestic disputes. And only recently have United States courts begun to address with any regularity the impact of international human rights law upon claims brought before them. ${ }^{4}$

Moreover, sensationalist media reporting in the United States creates a negative impression of civil rights issues in Canada. Canada is that place, goes an all-too-familiar refrain, being "torn apart" by bilingualism. As a result, government officials in the United States responsible for enforcing bilingualism in voting or education, as I was for four years, or lawyers representing Hispanic groups in litigation, tend to view any reference to Canada's experience in that regard as counterproductive.

Having said all this, however, it is still remarkable that American lawyers know so little about Canadian civil rights law. Our countries, both federal systems, share a common legal heritage, a host of social, economic and military interests and several thousand miles of border. This article is an attempt, my having joined a few years ago the small band of Americans focusing on such matters a few years ago, to rectify this situation somewhat and to explain why American civil rights lawyers and legal academics in the field are likely to gain professionally from following Canadian legal developments in the years to come.

\section{Judicial Protection of Civil Rights Prior to 1960}

One of the first questions that should come to an American lawyer's mind is how can it be that Canada, "the place being torn apart by bilingualism," has addressed so straightforwardly in its fundamental document four issues that continue to bedevil civil rights progress in the United States: rigorous constitutional protection against discrimination on bases other than race and religion; affirmative action; equal rights for women; and an explicit constitutional right to redress for violations of its provisions? The short answer is that these principles are the result of an almost forty year effort by Canadian legislative, not judicial, institutions to provide meaningful protections against discrimination.

Until April 1982, Canada's fundamental legal document was the British North America Act of 1867 (BNA Act). ${ }^{5}$ The BNA Act was

4. Filartiga v. Pena-Irala, 630 F.2d 876 (2d Cir. 1980) (torture); Fernandez v. Wilkinson, 505 F. Supp. 787 (D. Kan. 1980), aff'd, 654 F.2d 1382 (10th Cir. 1981) (refugees) Tel-Oren v. Libyan Arab Republic, 517 F. Supp. 542 (D.C.D.C. 1981) (hostages).

5. British North America Acts, 1867-1976, 30 \& 31 Vic., Ch. 3. (hereinafter cited as BNA Act). The 1982 Constitution incorporates much of the BNA Acts and provides them with new names. See Canada Act 1982, §53. 
concerned with other things than civil rights, as we in the United States would define them, although some Canadian scholars have suggested that a "little bill of rights" can be drawn from a few of its provisions. ${ }^{6}$ Rather, as a document enacted by the British Parliament to unite three colonies of British North America-the United Province of Canada (which became Ontario and Quebec), New Brunswick and Nova Scotia-it addressed principally how power would be exercised within this new governmental structure. First the doctrine of parliamentary supremacy similar, but not identical, to that in Great Britain was enshrined. ${ }^{7}$ Second, to the degree that parliamentary supremacy was tempered in the Act, it was caused by the provincial organization of Canada at the time, particularly the existence of a French-speaking area later to be known as the province of Quebec. Hence the Act made provision for the distribution of power between the federal (central) government and the provinces, setting out at great length what matters could be reached only by the former and what by the latter. ${ }^{8}$ The distribution was supposed to be exhaustive, that is, all governmental power was lodged either in the Parliament or provincial legislatures, with residual power residing in the central government, and mutually exclusive. Consequently, concepts of implied power and overlapping jurisdiction were foreign to the structure of the BNA Act. Contrast this arrangement with our original constitutional scheme in which principal focus was upon limiting the powers of the central government, leaving to the States and the people, in vague and general terms, those matters not explicitly delegated. 9 The upshot of the melding of parliamentary supremacy and federalism for Canada was

6. Hogg, Constitutional Law of Canada 421-422 (1977) (hereinafter cited as Hogg). For full discussions of the history and scope of the BNA Acts, see generally, Hogg and Whyte \& Lederman, Canadian Constitutional Law (1975) and Sabetti, "The Historical Context of Constitutional Change in Canada," 45 L. \& Contemp. Prob. 11 (1982).

7. One authority describes parliamentary supremacy as follows:

In the United Kingdom there are no limits to legislative power: there is no fundamental law which cannot be altered by ordinary parliamentary action; there is no constituent instrument which allocates some subject matters of legislation to the Parliament and denies others to it; and there is no bill of rights which denies to the Parliament the power to destroy or curtail civil liberties. Any law, upon any subject matter, no matter how outrageous is within the Parliament's competence. It follows, of course, that the courts have no power to deny the force of law to any statute enacted by the Parliament. Judicial review of legislation is unheard of in the United Kingdom.

Hogg at 197.

8. BNA Act, §§ $91 \& 92$. Sec. 91(7), for example, gives Parliament exclusive legislative authority over "Militia, Military and Naval Service and Defence." On the other hand, Sec. 92(12) leaves "The Solemnization of Marriage in the Province" solely to provincial regulation.

9. U.S. Const. Amends. IX and X. 
that each legislative body was supreme within its sphere-the Parliament in federal matters, provincial legislatures in theirs.

The Act was designed to accomplish two other objectives that should strike Americans strangely, given our experience. First, it protected, from federal or provincial encroachment, the existence of governmentally supported religious ("denominational") schools. ${ }^{10}$ Second, it ensured the use of both English and French in the Houses of Parliament, in the Quebec legislature and in any "pleading or process in or issuing from" the courts of Canada or Quebec.11 In other words, the BNA Act was directed at establishing the rights of religious and language groups against legislative change. One final comment about the Act: it did not create a Supreme Court. Instead, in much the same way that Art. III of the United States Constitution leaves to Congress the decision whether to create courts "inferior" to the Supreme Court,12 the BNA Act states simply that, "The Parliament of Canada may, notwithstanding anything in this Act, from time to time provide for the constitution, maintenance and organization of a general court of appeal for Canada . .."13 A Supreme Court of Canada was established in 1875 and other courts have also been created subsequently pursuant to that provision. ${ }^{14}$

This structure did not offer much possibility for rigorous protection of civil rights, if one excludes as I do the questions of religious schools and language rights. As one commentator observed, "the issue is which jurisdiction should have power to work the injustice, not whether the injustice should be prohibited completely." 15 There was, however, one line of attack against discriminatory provincial legislation that offered some initial promise, the concept of ultra vires. The argument was that the provinces were acting in areas given over by the BNA Act to the exclusive jurisdiction of the federal government. This argument proved successful in an 1890 case challenging a provincial enactment directing that "no Chinaman" be employed in a coal mine. The law was held to encroach upon the Parliament's exclusive jurisdiction over "naturalization and aliens." 16 Later cases found it harder to make such a clear distinction, upholding provincial legislation that held that "no Chinaman, Japanese or Indian shall . . be entitled to vote at any election"17 and prohibiting any "white woman or girl to reside or lodge in or to

10. BNA Act § 93 .

11. BNA Act $\S 133$.

12. U.S. Const. Art. III. § 1.

13. BNA Act $\S 101$.

14. Hogg at 121-125.

15. Hogg at 429, quoting Weiler, "The Supreme Court and the Law of Federalism," 23 U. Toronto L.J. 307, 343-44 (1973).

16. Union Colliery Co. of British Columbia v. Bryden, [1899] A.C. 580.

17. Cunningham v. Tomey Homma, [1903] A.C. 151. 
work in or . . to frequent any . . . business or amusement owned, kept or managed by a Chinaman."18 Provincial legislation was also attacked successfully as "criminal," a matter over which the federal government has exclusive jurisdiction by the terms of the BNA Act. The provinces, in contrast, were given exclusive jurisdiction over "property and civil rights in the Provinces" which, despite the familiar ring of "civil rights" to American ears, was designed to relate to most civil, as opposed to criminal, disputes arising within the province. ${ }^{19}$ But even this approach did not work to the challengers' advantage. For the courts held that the critical question was not whether a provincial law had criminal sanctions but rather whether its "pith and substance" was punishment of crime or was merely ancillary to the achievement of some other objective properly within its jurisdiction. Since the BNA Act granted the provinces exclusive jurisdiction over "generally all matters of a merely local or private nature in the province," the "pith and substance" approach left wide latitude for upholding legislation containing even criminal sanctions. $^{20}$

Common law doctrines were also invoked, with mixed results, to challenge discriminatory practices. The common law duty imposed upon innkeepers, common carriers and operators of monopolistic or privileged businesses affected with the public interest to serve everyone equally, unless there were some reasonable grounds for refusing, proved of almost no help in attacking discrimination in places of public accommodations. The courts narrowly construed the innkeeper rule, leaving owners of theaters, restaurants and taverns, and even motels to discriminate at will, against blacks in particular, on the basis of race. And the licensing of establishments serving alcoholic beverages was not held, in and of itself, to render them "affected with a public interest." 21 This story should come as

18. Quong-Wing v. The King, 49 S.C.R. 440 (1914).

19. BNA Act $\S 92(13)$. Laskin, "An Inquiry into the Diefenbaker Bill of Rights," 37 Can. B. Rev. 77, 114-16 (1959). Rand, "Some Aspects of Canadian Constitutionalism," Harvard Law School Occasional Pamphlet Number Two 19-20 (Holmes Lecture, 1960).

20. Bedard v. Dawson, [1923] S.C.R. 681. The distinctions drawn by the Canadian Supreme Court bear a striking resemblance to those developed by the U.S. Supreme Court to sort out permissible and impermissible state legislation affecting aliens. E.g., De Canas v. Bica, 423 U.S. 909 (1976), (upholding a California statute prohibiting employers from knowingly hiring illegal aliens.) The matter is further complicated by the fact that, although Sec. 91(27) gives the Parliament exclusive jurisdiction over the criminal law, Sec. 92(15) gives the provinces power to impose "punishment of fine, penalty or imprisonment for enforcing any law of the province made in relation to any matter coming within any classes of subjects" otherwise within provincial jurisdiction. The provinces have been able to rely upon this provision to enact penal laws which are "indistinguishable from certain federal criminal laws." Hogg at 277-78, 291-93.

21. See Christie v. The York Corporation, [1940] S.C.R. 139 (upholding tavern owner's refusal to serve blacks). See generally, Scott, Civil Liberties and Canadian 
little surprise to students of American law with respect to discrimination in places of public accommodation. From the Civil Rights Cases $^{22}$ in 1883 to passage of the Civil Rights Act of $1964,{ }^{23}$ the issue of whether proprietors could constitutionally refuse to serve otherwise acceptable patrons on the basis of race and have that decision enforced by police authorities was a matter of continuing debate. ${ }^{24}$ Only where there was a far closer nexus between the discrimination and state power, as in the case of a privately-owned, segregated restaurant located in a government facility, did United States courts find a constitutional violation. ${ }^{25}$ And very recent decisions have concluded that liquor licenses do not convert otherwise private establishments into state entities for constitutional purposes. ${ }^{26}$

Application of common law doctrine in the area of restrictive covenants, however, produced more favorable results. In one case, a covenant which read: "Land not to be sold to Jews or persons of objectionable nationality" was struck down in 1945.27 Another covenant, precluding any use or ownership of the land "by any person of Jewish, Hebrew, Semitic, Negro or colored race or blood" was declared void in $1951 .^{28}$ While the former decision was based, in part, upon the court's view that racially restrictive covenants were against public policy, a position explicitly eschewed in the public accommodations decisions, the latter took a narrower approach. It concluded that there was no basis under the common law for extending judicial protection to covenants that restricted not the future use of the property but rather the race or ethnic origin of future owners or users. ${ }^{29}$ Nevertheless, the Canadian courts were able to do something directly to end the use of restrictive covenants that American courts accomplished only by indirection: restrictive covenants could not be enforced by the latter only because to do so would constitute state action in violation of the Fourteenth Amendment. ${ }^{30}$

Two other judicial approaches deserve to be mentioned. The

Federalism 28-36 (1959); Schmeiser, Civil Liberties in Canada 262-77 (1964) and Tarnopolsky, Discrimination and the Law in Canada 1-24 (1982).

22. 109 U.S. 3 (1883)

23. 42 U.S.C. $\S \S 2000 \mathrm{a}$ et seq.

24. See, Bell v. Maryland, 378 U.S. 226 (1964). It was for this reason that the Public Accommodations provision of the 1964 Act (Title II) was enacted based upon the Commerce Power, as well as upon Sec. 5 of the Fourteenth Amendment. The Supreme Court's decision upholding Title II's constitutionality relied solely upon the Commerce Power. Heart of Atlanta Motel v. United States, 379 U.S. 241 (1964).

25. Burton v. Wilmington Parking Authority, 365 U.S. 715 (1961).

26. See for example, Moose Lodge No. 107 v. Irvis, 407 U.S. 163 (1972).

27. Re Drummond Wren, 4 D.L.R. 674 (1945).

28. Noble v. Wolf and Alley, [1951] S.C.R. 64 .

29. See generally, Smout, "An Inquiry into the Law on Racial and Religious Restraints on Alienation," 30 Can. B. Rev. 863 (1952).

30. Shelley v. Kraemer, 334 U.S. 1 (1948). 
first has been referred to as the "implied bill of rights" theory. Some decisions in the speech and religion areas, from the late 1930s to as late as 1957, had contained suggestions that certain matters were, contrary to the "exhaustive distribution" scheme of the BNA Act, ultra vires the authority of both the provincial legislatures and the Parliament to curtail. The basis for such a reading was essentially that the BNA Act envisioned a parliamentary form of government in which free and open discussion was central to its effectiveness. ${ }^{31}$ In 1978, however, the Supreme Court of Canada explicitly rejected any notion of an implied bill of rights. ${ }^{32}$ The second involves the principle of validity - that every official act must be justified by law. As under English law, "with few exceptions, actions which infringe the liberty of the subject require authority of a statute." 33 This principle was invoked by the Supreme Court in the 1950 s to halt a series of actions taken by the government of Quebec to suppress the activities of Jehovah's Witnesses, ${ }^{34}$ very reminiscent of similar actions in the United States during the 1940s. ${ }^{35}$

While these approaches served to limit somewhat the degree to which the provinces could violate civil rights, no such brakes were available to curtail federal government abuses. One need only look at Parliament's treatment of Japanese-Canadians after the bombing of Pearl Harbor in December 1941. Most Americans are thoroughly familiar with, and many ashamed of, the way in which our government evacuated and interned Japanese-Americans during World War II. ${ }^{36}$ In fact, a special committee created by the Congress has just completed a set of recommendations, urging among other things, the payment of reparations, for the personal indignities and property loss suffered by Japanese-Americans during that period. ${ }^{37}$

Though it should provide little solace to Americans, Canada seems to have dealt with its citizens and residents of Japanese de-

31. Reference re Alberta Statutes (The Alberta Press Case) 1928 S.C.R. 100; Saumur v. City of Quebec, 4 D.L.R. 641 (1953); and Switzman v. Elbling, 1957 S.C.R. 285.

32. A.G. Canada v. Dupond, 84 D.L.R. 3d 420 (1978).

33. Hogg at 419.

34. Chaput v. Romain, 1 D.L.R. 2d 241 (1955); Roncarelli v. Duplessis, 16 D.L.R. 2d 689 (1959); and Lamb v. Benoit, 17 D.L.R. 2d 369 (1959). In Roncarelli, the then Premier of Quebec was found by the Supreme Court to have acted without legal authority in ordering the cancellation of the liquor license of a Jehovah's Witness who had been furnishing bail for other Witnesses charged with various offenses. For a full discussion of these cases, see Scott, supra n. 21 at 12-13, 42-50.

35. Cantwell v. Connecticut, 310 U.S. 296 (1940); Minersville School Dist. v. Gobitis, 310 U.S. 586 (1940); and Murdock v. Pennsylvania, 319 U.S. 195 (1943).

36. Hirabayashi v. United States, 320 U.S. 81 (1943); Korematsu v. United States, 323 U.S. 214 (1944); and Rostow, "The Japanese American Cases-A Disaster," 54 Yale L.J. 489 (1945). See also Irons, Justice at War (1983).

37. Personal Justice Denied, Report of Commission on Wartime Relocation and Internment of Civilians, reported on in N.Y. Times, 25 Feb. 1983 at 1, Col. 5. 
scent even more harshly during that same period, employing techniques going far beyond internment to reduce their perceived threat to national security. ${ }^{38}$ In early 1942, those living along the Pacific Coast of Canada, in the province of British Columbia, were rounded up by federal officials pursuant to the War Measures Act. Though some were sent to work on beet farms in provinces farther to the east, most were interned in camps located in the interior of British Columbia. Their land, homes and other property were confiscated.

Gradually, those in British Columbia camps were allowed to move east of the Canadian Rocky Mountains with the understanding that any attempt to return to British Columbia would be severely punished. Alternatively, Japanese Canadians who did not want to relocate east of the Rockies were given an opportunity to be "repatriated," returned to Japan once such action became possible. Those who opted to move east were denied by Parliament the right to vote in federal elections.

Even after the surrender of Japan in August 1945, the Canadian government's mistreatment of Japanese citizens and residents did not abate immediately. Those sixteen or older who had earlier "opted" for repatriation were ordered deported, along with their wives and children. Though this deportation program was upheld as legal by the Canadian courts and on appeal to the British Privy Council, ${ }^{39}$ the government ultimately terminated it in the face of strong public opposition. But by the time the orders had been rescinded, almost 4,000 persons of Japanese origin had been deported.

It was not until 1948 that Japanese Canadians regained the right to vote in federal elections and 1949 before they could return to the Pacific Coast. Throughout this entire period, not one Japanese Canadian was even charged with espionage. This was as clear an object lesson on the supremacy of Parliament within its sphere as can be imagined.

\section{The Growth of Human Rights Agencies}

Given what one commentator called the Canadian courts' "niggardly approach" 40 under the common law to addressing discrimination, the question remained of what other institutions, if any, would

38. Much of the discussion with respect to Canada's treatment of its Japanese citizens and residents is drawn from Schmeiser, supra n. 21 at 260-61; Adachi, The Enemy That Never Was 199-354 (1976); and Berger, Fragile Freedoms 93-126 (1981).

39. Co-op Committee on Japanese Canadians v. A.G. Can., 1947 A.C. 88. Until 1949, Supreme Court decisions and certain provincial court decisions could be reviewed by the Judicial Committee of the Privy Council. The Supreme Court became the final judicial authority in Canada thereafter in both provincial and federal cases. Russell, The Supreme Court of Canada as a Bilingual and Bicultural Institution 25-38 (1969).

40. Schmeiser, supra n. 21 at 277. 
fill the void. As another remarked, "By 1940, it was clear that Canadian courts regarded racial discrimination as neither immoral nor illegal."41 Surprisingly, given the earlier discriminatory practices described above, the exclusive jurisdiction of provincial legislatures was exercised beginning in the mid-1940s not to violate civil rights but rather to afford them statutory protection. ${ }^{42}$

Undoubtedly motivated in significant part by the enormity of the Holocaust and other Nazi injustices, Ontario passed the first human rights statute during this period. The Ontario Racial Discrimination Act declared, generally, that racial and religious discrimination was contrary to public policy. More specifically, it prohibited the practice of posting "white only" signs in places of public accommodations. In 1947, Saskatchewan enacted the first Bill of Rights which extended protections beyond Ontario's prohibition against racial and religious discrimination to include the proclamation of certain political freedoms, such as of speech and of the press, and the right to procedural safeguards in the criminal process. In 1951, Ontario expanded the scope of its human rights legislation by enacting the first Fair Employment Practices Act and, in 1954, a Fair Accommodations Practices Act. ${ }^{43}$ Despite their laudable objectives, however, these statutes were only modestly effective for two basic reasons. First, the entire enforcement responsibility was placed upon the victims of discrimination. And second, enforcement was by way of criminal process in the courts, with all the problems of time, money and proof beyond a reasonable doubt associated with that approach. ${ }^{44}$

Consequently, it was not until Ontario enacted its 1962 Human Rights Code that the era of truly effective enforcement of provincial human rights legislation began. That code consolidated all of Ontario's human rights statutes and created an administrative body, the Ontario Human Rights Commission, with the power and resources to enforce its provisions. The Ontario approach, addressing substantively discrimination in public accommodations, employment and housing, and relying procedurally upon a Commission with broad powers of enforcement, was adopted subsequently by every other Canadian province.

While there are some minor differences among the provinces in the organization and operation of their human rights commissions,

41. Hunter, "The Origin, Development and Interpretation of Human Rights Legislation," in MacDonald \& Humphrey (eds.), The Practice of Freedom (1979).

42. See generally, for a history of the growth of human rights agencies, Hunter supra n. 41; Tarnopolsky, supra n. 21 at 25-37; Tarnopolsky, "The Control of Racial Discrimination," in MacDonald \& Humphrey (eds.), id. at 289-301.

43. Tarnopolsky, "The Control of Racial Discrimination," id. at 296.

44. Tarnopolsky, The Canadian Bill of Rights 69 (1975). 
the basic outlines do not differ markedly. ${ }^{45}$ Members of the commission are appointed by the provincial government. The staffs are civil servants. Each commission has the power to investigate complaints within its jurisdiction and to seek conciliation. Where conciliation fails, the commission is authorized to order, when it deems appropriate, the convening of a "board of inquiry" to conduct what is, in effect, an administrative proceeding. Unlike the United States model, this administrative body is established ad hoc; its membership is drawn from distinguished members of the bar and of law school faculties for the purpose of hearing a particular dispute, not to sit on a continuing basis. Before the board of inquiry, the commission has the burden of establishing "on the balance of probabilities" (a civil standard) that the antidiscrimination laws have been violated. Where a violation is found, the board may order a variety of monetary and non-monetary remedies. An appeal of the board's decision may be taken by the Commission or the charged party up through provincial courts and, from there, even to the Supreme Court of Canada. ${ }^{46}$ Noncompliance with board orders can result in the imposition of penal sanctions or the granting of injunctive relief by provincial courts.

American lawyers should find several features of this process curious, given United States practices. First, the provinces (our States), not the federal government, took the initiative in addressing problems of discrimination. It would have been inconceivable, for example, for blacks to look to the states of the Deep South in the 1940 s and 1950s for protection against discrimination. In our country, federal legislation from 1957 to the present has been primarily responsible for providing statutory safeguards against discrimination. Second, the political (the provincial cabinet officials and the legislatures), not the judicial process, was responsible for establishing that discrimination was contrary to public policy and should be prohibited by law. The initial impetus for the civil rights movement in the United States came from the courts. ${ }^{47}$ While the federal courts played the major role in this process, ${ }^{48}$ on occasion even state courts took the lead over their legislatures in addressing racial discrimination. ${ }^{49}$ And third, effective enforcement of antidiscrimination

45. Hunter, supra n. 41 at 95-97; Tarnopolsky, "The Control of Racial Discrimination," supra n. 42 at 301-05.

46. The Supreme Court of Canada has ruled that it has appellate jurisdiction over human rights agency or board of inquiry decisions. Bell v. Ontario Human Rights Commission, [1971] S.C.R. 756. See generally, Weiler, In the Last Resort 120-54 (1974).

47. See generally, Dorsen, Bender, Neuborne, Law, 2 Emerson, Haber and Dorsen's Political and Civil Rights in the United States (1979).

48. Kluger, Simple Justice (1976).

49. Gebhart v. Belton, 91 A.2d 137 (1952) (Delaware Supreme Court's affirmance of lower court desegregation order which became one of the cases reviewed by the 
laws was secured in Canada by resort to the administrative process, rather than to the courts by way of private rights of action. In the United States, the Congress has consistently refused to give administrative agencies effective enforcement powers, such as "cease and desist" authority enjoyed by non-civil rights regulatory bodies like the National Labor Relations Board (NLRB) and the Interstate Commerce Commission (ICC). Rather, they must, themselves, resort to federal courts in order to obtain compliance with the law, as in the case of the Equal Employment Opportunities Commission (EEOC). ${ }^{50}$ What powers they do possess have, for a variety of reasons, not been exercised rigorously or consistently. ${ }^{51}$ As a consequence, our civil rights statutes have tended to grant an explicit private right of court action and the courts have often construed certain statutes lacking such express authority to grant an "implied" right of action. ${ }^{52}$

\section{Ontario}

While it is not possible in this context to provide an exhaustive description of the scope and effectiveness of each provincial human rights enforcement machinery, a look at the Ontario experience may be instructive. The Ontario Human Rights Code of 1981,53 which became effective on 15 June 1982, provides that every person has a right to freedom from discrimination in the areas of (1) services, goods and facilities, (2) the "occupany of accommodation" (rental and sale of housing), (3) contracts, (4) employment and (5) membership in vocational associations and trade unions. The Code applies to private parties, corporations, other business and labor organizations, municipalities and even the provincial government itself.

Discrimination is prohibited on a list of grounds that has no parallel, to my knowledge, in United States law. Included, for all purposes, are race, ancestry, place of origin, color, ethnic origin, citizenship, creed, sex, handicap, marital status (includes cohabitation, widowhood, separation) and family status (parent-child relationship). ${ }^{54}$ Some limitations are imposed, however, with respect to

U.S. Supreme Court along with Brown). It is true, of course, that early leadership in this area was displayed by legislatures in certain non-Southern jurisdictions. See generally in this respect, Murray, States' Laws on Race and Color (1950).

50. Alexander v. Gardner-Denver Co., 415 U.S. 36, $44-45$ (1974).

51. Adams v. Richardson, 480 F.2d 1259 (D.C. Cir. 1973). Block, "Enforcement of Title VI Compliance Agreements by Third Party Beneficiaries," 18 Harv. Civ. RightsCiv. Lib. L. Rev. 1 (1983).

52. Cannon v. University of Chicago, 441 U.S. 677 (1979).

53. Ont. Stat. $1981 \mathrm{ch}$. 53. (Ontario Human Rights Code of 1981.) The Code was significantly revised in 1981.

54. The Quebec Charter of Human Rights and Freedoms is the only provincial 
the remaining grounds. Age discrimination in employment covers only those between 18 and 65; the age span is 18 years and over in all other areas. One cannot be discriminated against in the area of accommodation based upon the receipt of public assistance. And a record of provincial or pardoned federal offenses cannot be a bar to employment. More generally, the Act defines impermissible conduct as including direct discrimination, harrassment (sexual and otherwise), indirect discrimination (acting through an agent), discrimination because of association, constructive discrimination (disparate effect), reprisals and discriminatory signs and notices. And the Code excludes from its prohibitions special programs "designed to relieve hardship or economic disadvantage or to assist disadvantaged persons or groups to achieve or attempt to achieve equal opportunity or that is likely to contribute to the elimination of the infringement of rights" granted elsewhere in the legislation. ${ }^{55}$

Ontario's enforcement of the Code may parallel our efforts in the United States perhaps more closely than that of any other province because of its focus upon problems of racial discrimination. Canada's relatively small black and other racial minority groups have tended to settle in that province-successive waves of American blacks, blacks from the Caribbean, East Indian and Southeast Asian immigrants constituting the major components of this population. ${ }^{56}$ The work of the Commission reflects their presence. During the entire existence of the Ontario Human Rights Commission, complaints alleging discrimination on the basis of race and color have constituted the largest single category on its docket. From 1974 to 1982 , they have accounted for between 36 and 56 percent of the workload. In 1981-82, 83 percent of the complaints to the Commission involved employment; 40 percent of that category had to do with race or color. ${ }^{57}$ The second largest category of complaints has involved allegations of sex and marital status discrimination, running from 23 to 37 percent between 1974 and 1982. ${ }^{58}$ While it is difficult to assess from afar the actual effectiveness of the Ontario

legislation that explicitly forbids discrimination on grounds of sexual orientation. Que. Rev. Stat. 1975 ch. 6 s. 10. Tarnopolsky, supra n. 21 at 324.

55. Ontario Human Rights Code, § 13(1).

56. For a comprehensive treatment of the emigration of blacks to Canada see generally, Winks, The Blacks in Canada (1971). Winks writes, at 484, that as of 1970, blacks in Canada had never constituted more than five percent of the population of any province. A recent report done for the Metropolitan Toronto (Ontario) Government notes that since 1967 Jamaica, Guyana, Trinidad/Tobago and India have replaced European source countries in the five highest ranking immigrant groups coming to that city in the 1970s. Asians, West Indians and Africans composed $59 \%$ of the immigrant flow to Toronto in 1976. Now Is Not Too Late (Task Force on Human Relations Report to Council of Metropolitan Toronto) 37 (November 1977).

57. 1981-82 Annual Report, Ontario Human Rights Commission at 23, 55.

58. Id., 1980-81 Annual Report at 14. 
Commission, particularly in terms of how much more could have been done than was accomplished in fact, ${ }^{59}$ it clearly appears to be having a growing impact upon civil rights and liberties within the province. In 1981-82 it achieved settlements involving cash payments, specific performance and affirmative action in several hundred cases in the areas of employment, housing and public accommodation, services and facilities. ${ }^{60}$ Boards of inquiry convened pursuant to the Human Rights Code have also established an impressive list of legal principles with respect to the nature of prohibited discrimination and of remedial devices to correct for violations of the law. Many of these rulings have subsequently been addressed explicitly by amendments to the Code or other provincial legislation. For example, in 1970, a board concluded that derogatory language by a plant foreman to a black employee might contravene the Code's prohibition against discrimination with regard to any term or condition of employment. "Term or condition of employment," the board chairman concluded, had to include within its definition consideration of the atmosphere in the workplace and working conditions. ${ }^{61}$ In 1967, two female hospital aides alleged discrimination on the grounds that they were doing the same work but not being paid as much as male hospital attendants. The board, agreeing that the Code required equal pay for equal work, ruled in their favor and recommended that the employer revise its job classification and compensation structure entirely to reflect that principle. ${ }^{62}$ In 1973, a board awarded general damages (financial compensation to alleviate the humiliation and indignity of the complainant) in addition to an award for compensatory damages (out-ofpocket expenses) to a woman denied housing on the basis of race. ${ }^{63}$ Since that time, general damages as high as $\$ 8,000$ have been awarded. In 1980, a board found the Liquor Board of Ontario, a governmental agency, guilty of sex discrimination and ordered it to establish an affirmative action program to increase the employment of women, in addition to providing the complainant with compensatory and general damages and a letter of apology. The affirmative action

59. One researcher concluded, for example, that "only approximately one of every ten individuals who suffers some degree of discrimination actually complains" to the Ontario Human Rights Commission; Head, The Black Presence in the Canadian Mosaic 74 (1975). See A Statement of Concerns and Recommendations Regarding Human Rights in Ontario, Report to Government of Ontario by the Urban Alliance on Race Relations (November 1980). On the other hand, complaints of race/color discrimination decreased in 1982-83 from $42 \%$ in 1981-82 to only $27 \%$. 1982-83 Annual Report at 23.

60. Annual Report, supra n. 57 at 53-57. This trend continues. See 1982-83 Annual Report at 29.

61. Simms v. Ford Motor Co., Annual Report, supra n. 57 at 13.

62. Byron et al v. Children's Psychiatric Research Institute, id. at 15.

63. Gabbidon v. Golas, id. 
program was to be coordinated with and monitored by another government agency charged with advancing employment opportunities for women. ${ }^{64}$ And during the same year, a board adopted the Griggs v. Duke Power ${ }^{65}$ effects test established by the U.S. Supreme Court, to strike down a $5^{\prime} 10^{\prime \prime}$ height requirement imposed by the Ottawa Police Department that systematically excluded most women from being considered for employment. ${ }^{66}$

\section{Federal}

Following the lead of the provinces, and spurred particularly by Canada's ratification in 1976 of the Universal Declaration of Human Rights, the federal government decided to establish its own human rights agency. The Canadian Human Rights Commission was created by Parliament in July 1977 to carry out responsibilities very similar to those discharged by provincial commissions. Its jurisdiction is limited, however, to federal entities (departments, agencies and corporations) to the Canadian Armed Forces, the Royal Canadian Mounted Police and to businesses under federal jurisdiction, such as banks, airlines, interprovincial railway companies, and trucking and uranium mining companies. ${ }^{67}$ What this means, as a practical matter, is that the Canadian Human Rights Commission has jurisdiction over only about $20 \%$ of the employers in the country; provincial jurisdiction reaches the remaining vast percentage of employment situations. ${ }^{68}$

The Canadian Human Rights Act, amended most recently in March 1983, parallels substantively most of the Ontario Code provisions. ${ }^{69}$ Two provisions of the Act deserve special note, however. The first prohibits the repeated communication of hate messages by means of the telephone. ${ }^{70}$ In 1979, a board of inquiry (called a Human Rights Tribunal under the Act) found that a group in To(1980)

64. Hendry v. L.C.B.O., 1 Canadian Human Rights Reporter (C.H.R.R.) D/160

65. 401 U.S. 424 (1971).

66. Colfer v. Metro Toronto Bd. of Commissioners of Police, 1978-79 Annual Report, Ontario Human Rights Commission at 25. A comprehensive listing of provincial boards of inquiry decisions can be found in Tarnopolsky, supra n. 21 at 533-59.

67. The Commission did not become operational until 1 March 1978. For a general discussion of the Commission, its history and enforcement experience pre-1979, see Fairweather, "The Canadian Human Rights Commission," in The Practice of Freedom, supra n. 41 at 309.

68. Id. at 310. Act).

69. Can. Stat. 1980-81-82-83, ch. 143, §§ 1-2, 4-15, $19-25$ (Canadian Human Rights

70. Canadian Human Rights Act, $\$ \S 13(1)-(3)$. United States law, constrained by the free speech guarantees of the First Amendment to the Constitution, prohibits the broadcasting of only "obscene, indecent or profane language," F.C.C. v. Pacifica Foundation, 438 U.S. 726 (1978). And though the United States Supreme Court, upheld a group libel statute in the 1950s, Beauharnais v. Illinois, 343 U.S. 250 (1952), there is 
ronto was operating a tape recorded message which could be reached by telephone in violation of that provision. The message proclaimed the supremacy of the white race and attacked Jews for attempting to destroy the white race by means of Communism. When the group refused to comply with the tribunal's order to discontinue the message, the Commission successfully sought judicial contempt citations against it. The group's leader was sentenced to one year in jail and the group was fined $\$ 5,000$. The recording was discontinued in $1980 . .^{71}$

The second goes beyond the reach of United States law to make it a discriminatory practice for an employer to pay different wages to males and females who are "performing work of equal value."72 Federal law had required "equal pay for equal work" since about 1956. That approach proved ineffective, however, in reducing the great gap between wages of men and women because of the narrow interpretation given to the concept of "equal work." Jobs had to be nearly identical before the principle could be invoked successfully. The "equal pay for work of equal value" concept was developed by the International Labor Organization in 1951 in the Rome Convention, to which Canada is a signatory. ${ }^{73}$

The Canadian provision does not purport to be designed to equalize wages for men and women, irrespective of market factors, overnight. Rather, it proceeds from the premise that the principle of supply and demand has been distorted by stereotyped concepts of male and female roles such that jobs that provide greater benefits

substantial question whether that decision still constitutes good law. See Gunther, Constitutional Law 1329-40 (1980).

71. Canadian Human Rights Commission v. John Ross Taylor and the Western Guard Party, 1981 Annual Report, Canadian Human Rights Commission. Canada's experience with racist hate gyoups parallels that of the United States. The Ku Klux Klan began its first attempts to organize in Canada in Montreal in 1921. During the 1920 s, though it operated in several provinces, the Klan's major base of operation was British Columbia where it purported to fight "socialist-communist tendencies" of Eastern European immigrant groups. After going into decline in the 1940s and 1950s, the Klan reappeared in Canada in Ontario in 1965, claiming responsibility for crossburnings and desecration of churches in black communities. Since then it has operated off and on, forming an alliance with the Western Guard Party. In June 1980, after gaining support from United States Klan leaders, the Canadian Klan opened up headquarters in Toronto. McAlpine, Report Arising Out of The Activities of the Ku Klux Klan in British Columbia, submitted to J.H Heinrich, Minister of Labor for the Province of British Columbia (30 April 1981).

72. Canadian Human Rights Act $\S 11(1)-(6)$. The degree to which this doctrine may be invoked in the U.S. under federal employment discrimination law continues to be a subject of vigorous debate. See County of Washington $v$. Gunther, 452 U.S. 161 (1981) and Note, "Equal Pay, Comparable Work and Job Evaluation," 90 Yale L.J. 657 (1981). A number of states, however, have enacted statutes that require equal pay for "comparable work." See Gasaway, "Comparable Worth: A Post-Gunther Overview." 69 Geo. L.J. 1123, 1147-49 (1981).

73. Canadian Human Rights Commission, Methodology and Principles for Applying Section 11 of the Canadian Human Rights Act. 
than others have been undervalued because the former were held principally by women, the latter by men. In order to counteract this traditional distortion in the market, the Act requires that employers engage in detailed and thorough job evaluation procedures, assessing the value of the work performed in terms of skill, effort and responsibility required in performance of the work and conditions under which the work is performed. ${ }^{74} \mathrm{~A}$ recent settlement demonstrates that this new approach is achieving results. In 1980, 470 federal librarians were brought into equal pay for work of equal value with male historical researchers. The total amount of back pay awarded to the librarians, $66 \%$ of whom were women, came to over $\$ 2.3$ million. Individual librarians received back pay of up to $\$ 5,900$ each, and their salaries were raised by adjustments of $\$ 500$ to $\$ 2,500 .^{75}$

To the extent that courts have been asked to review determinations by provincial and federal human rights agencies, they have responded in ways that some observers believe have tended to curtail the scope and reach of administrative efforts. Three cases have been regarded as particularly troubling in this respect. In the first, the Supreme Court of Canada construed a provision of the Ontario Human Rights Code prohibiting housing discrimination in such a way as to exclude from its coverage most lower cost urban dwellings. Consequently, the very type of housing likely to be sought by minority group members could, given the court's interpretation, be denied to them on the grounds of race or other reasons prohibited by the Code. ${ }^{76}$ The second case involved a complaint by a gay rights group brought against a Vancouver newspaper under the British Columbia Human Rights Code for refusing to carry the group's adver. tisement for a magazine which promoted homosexuality. The Code prohibits discrimination in the provision or ${ }_{C}$ the denial of "any accommodation, service or facility customarily available to the public unless reasonable cause exists" for such action. The Supreme Court of Canada held that the Code had not been violated. ${ }^{77}$ In the final

74. Equal Wages Guidelines, Can. Gaz. II SI/82-2 (13 Jan. 1982).

75. 1980 Annual Report, Canadian Human Rights Commission at 23. In 1982, a major "equal pay for work of equal value" complaint was settled. Under the agreement, more than 3,000 people received $\$ 17$ million in back pay and a total annual salary increase of $\$ 12$ million. 1982 Annual Report at 26-27. For background on the earlier stages of this case involving the General Services Category of federal employees, see Tarnopolsky, supra n. 21 at 420.

76. Bell v. Ontario Human Rights Commission, supra, n. 46. the decision is criticized in Weiler, supra, n. 46 at $139-43$.

77. Gay Alliance Toward Equality v. The Vancouver Sun, 97 D.L.R. 3d 577 (1979). For a critical discussion of the decision, see McPherson, "Developments in Constitutional Law: The 1978-79 Term," in Belobaba \& Gertner (eds.), The Supreme Court Law Review Vol. I, 122-130 (1980). Another commentator, however, viewed the case as an example of administrative agency overreaching. Hunter, supra, n. 41 at 84-90. 
case, the Supreme Court held that a government agency in the province of Alberta lacked jurisdiction to establish an affirmative action program to ensure that members of five Indian tribes received preferential treatment in hiring and business opportunities on an oil exploration project. ${ }^{78}$ Though the provincial legislatures in Ontario and Alberta amended their human rights statutes to overturn, in effect, the restrictive judicial interpretations on housing discrimination and affirmative action, ${ }^{79}$ the momentum of civil rights enforcement was retarded, nevertheless. ${ }^{80}$

\section{The Canadian Bill of Rights ${ }^{81}$}

During the period of development of human rights machinery in the provinces, federal legislators had not lost sight of the fact that Canada's fundamental document was essentially silent on matters of civil rights and civil liberties. Beginning in about 1945, a movement to amend the British North America Act to correct this omission got underway. Because of the cumbersome procedure associated with amending the Act, however, the most that could be achieved by 1960 was the enactment of a federal statute, not a constitutional amendment, applicable only to the central government. The provinces, acting within their proper sphere, were not affected at all by this legislation, the Canadian Bill of Rights of $1960 .{ }^{82}$ It was thought, however, that at least this much should be done as an interim measure, pending the development of a greater consensus for amending the British North America Act. ${ }^{83}$

In much the way that the Saskatchewan Bill of Rights ${ }^{84}$ is structured, the 1960 Act addresses itself to a list of freedoms which per-

78. Athabasca Tribal Council v. Amoco Canada Petroleum Co. Ltd., 124 D.L.R. 3d. 1 (1981) For an extended discussion of this case, see Tarnopolsky, "The Equality Rights" in Tarnopolsky \& Beaudoin (eds.), Canadian Charter of Rights and Freedoms 431-433 (1982).

79. Hunter, supra n. 41 at 92 ; Tarnopolsky, id. at 433.

80. There have been two recent Supreme Court decisions, however, that seem, at least to an outsider, as generally supportive of human rights agency action. In Board of Governors of Seneca College v. Bhaduria, 124 D.L.R. 3d 193 (1981), the Court declined to recognize the new tort of racial discrimination, holding that the mechanism established under the Ontario Human Rights Code was the complainant's only avenue to redress. See Tarnopolsky, supra n. 21 at $482-85$ for a discussion of this case in detail. And Ontario Human Rights Commission v. Borough of Etobicoke, 132 D.L.R. 3d 14 (1982) upheld a board of inquiry's determination that the Borough's mandatory retirement age of 60 for firefighters was not a bona fide occupational qualification under the Ontario Human Rights Code.

81. Tarnopolsky, The Canadian Bill of Rights (1975) is the definitive work on the development and early application of the Bill of Rights.

82. Can Stat. 1960 ch. 44 (Can. Rev. Stat. 1970, Appendix III).

83. Id. at 11-14. See also Scott, "Dominion Jurisdiction Over Human Rights and Fundamental Freedoms," 27 Can. B. Rev. 497-511 (1952) for a discussion of the problems presented by any effort to amend the B.N.A. Act.

84. See text, supra at 12. 
sons in Canada have a right to enjoy without discrimination, such as freedom of religion and speech. ${ }^{85}$ Though discrimination based upon race, national origin, color, religion or sex is explicitly prohibited by the Bill, it has been construed to reach discrimination on other grounds, as well. ${ }^{86}$ The Canadian Bill of Rights also sets out a number of procedural protections to be afforded persons involved in legal proceedings, particularly those subject to criminal prosecution. ${ }^{87}$ Like human rights legislation in three provinces-including Saskatchewan-the Bill of Rights contains what is generally referred to as a non obstante or override clause. ${ }^{88}$ It gives Parliament the power to curtail or suspend the operation of certain provisions of the Bill of Rights by enacting simple legislation explicitly to that effect. Hence, a law found to violate freedom of speech would fall in the face of the Bill of Rights unless Parliament made clear its intentions to have the restrictive enactment operate irrespective of the 1960 legislation. ${ }^{89}$ Given the supremacy of the Parliament within its sphere under the British North America Act, the courts had some difficulty discerning their role under the Bill of Rights. Were they supposed to engage in judicial review of acts of Parliament, declaring them illegal when they conflicted with guarantees under the Bill of Rights, with the understanding that subsequent legislative action would be able to override their decision? Was the Bill of Rights to be viewed as merely another statute, subject to traditional narrowing canons of construction, or was it intended to be a "quasi-constitutional" document, entitled to be construed liberally to achieve its underlying objectives? ${ }^{90}$

Largely because of this ambivalence, the courts tended generally to avoid reliance upon the Bill of Rights for the first ten years of its existence. Where it did come into play, the courts found creative ways of holding that the challenged law and the Bill of Rights were not in conflict, as, for example, in a 1963 decision that the Lord's Day Act (Canada's Sunday Closing Law) did not violate the Bill of Rights guarantee of freedom of religion. The majority opinion for the Supreme Court of Canada simply concluded that, since such laws existed prior to the Bill of Rights' coming into force, Parliament could not have viewed them as inconsistent with that latter stat-

85. Bill of Rights, $\S 1$.

86. Regina v. Burnshine 1 S.C.R. 693 (1975) (discriminatory sentencing).

87. Bill of Rights, $\S 2$.

88. Tarnopolsky, "A Full Overview of the Charter," The Canadian Charter of Rights and Freedoms 108 (Continuing Legal Education Seminar, Ottawa, 29 May 1982).

89. Hogg, "A Comparison of the Canadian Charter of Rights and Freedoms with the Canadian Bill of Rights," in Tarnopolsky \& Beaudoin (eds.), supra n. 78 at 10-12.

90. Gold, "Equality Before the Law in the Supreme Court of Canada: A Case Study," 18 Osgoode Hall L.J. 337-39 (1980). 
ute. ${ }^{91}$ This view of the relationship of the Bill of Rights to practices considered legal prior to its adoption, often referred to as the "frozen concepts" doctrine, became a major obstacle to any evolutionary development of its provision. ${ }^{92}$

In 1969, however, the Supreme Court decision in Regina $v$. Drybones $^{93}$ appeared to herald a much more liberal application of the Bill of Rights, giving it greater significance than that afforded a simple statute. In Drybones, the Court was faced with the question of whether provisions of the federal Indian Act violated rights guaranteed by the Bill of Rights to "equality before the law and protection of the law" without discrimination on the basis of race. Drybones, an Indian, had been prosecuted for being intoxicated "off a reserve" (Indian reservation) under a provision that had the effect of making an Indian criminally liable for being drunk even in private. Non-Indians in the Northwest Territory, an area subject to federal control where the case arose, could be prosecuted, in contrast, only for public drunkenness. Penalties for intoxication under the Indian Act were also different and harsher in certain respects than those applicable to non-Indians. The Supreme Court concluded that the Indian Act provision was contrary to the Bill's equality provision, and thereby, rendered "inoperative." According to the majority opinion, the Bill of Rights was designed to prohibit laws making it "an offense punishable at law on account of race, for a person to do something which all Canadians who are not members of that race may do with impunity." 94 The Court also appeared to reject, at least in this context, the "frozen concepts" doctrine, since the Indian Act provision at issue had been in effect on 10 August 1960 when the Bill of Rights became law.

The elevated status accorded the Bill of Rights in Drybones was not to endure, however. During the 1970s the Supreme Court of Canada decided nine other cases interpreting the "equality before the law and protection of the law" provision. ${ }^{95}$ All upheld statutes challenged as being repugnant to the Bill of Rights. Three of those cases, in the areas of sex and race discrimination need special mention.

In the 1973 Lavell $^{96}$ decision, two Indian women, alleging sex

91. Robertson and Rosetanni v. The Queen, 41 D.L.R. 2d 485 (1964). Note the similarity between Robertson and Braunfeld v. Brown, 366 U.S. 599 (1961).

92. Tarnopolsky, "The Historical and Constitutional Context of the Proposed Canadian Charter of Rights and Freedoms," 44 L. \& Contemp. Prob. 182-92 (1981).

93. 9 D.L.R. 3d 473 (1970).

94. Id. at 484. Brown v. Board of Education, supra n. 1 is cited by a concurring Justice for the same proposition. Hall, J. at 486.

95. Baines, "Women, Human Rights and the Constitution," in Doerr \& Carrier (eds.), Women and the Constitution in Canada 41 (1981).

96. A.G. Can. v. Lavell Isaac v. Bedard, 38 D.L.R. 3d 481 (1974). 
discrimination, challenged under the Bill another provision of the Indian Act that allowed Indian men, but not Indian women, to marry non-Indians without losing tribal rights. Both women had been declared by their tribes ineligible to live on reserve lands and participate in tribal affairs. The Supreme Court found that no denial of equality before the law had taken place and rejected the women's claims, despite what one dissenting Justice called the "excommunication of Indian women"97 effected by the challenged statute. The Canadian Supreme Court, it should be noted, is not alone in finding difficult the application of standard sex discrimination concepts to controversies involving tribal Indians. In 1977, the U.S. Supreme Court confronted a similar challenge under the Indian Bill of Rights of 1968 and reached essentially the same result. Though the decision ultimately turned on the Court's conclusion that Congress had not intended to grant jurisdiction to non-tribal courts to hear such challenges, the majority's underlying arguments bear striking resemblance to those of the Canadian court. ${ }^{98}$

Yet another provision of the Indian Act, this one having to do with the power of Indian women to administer the estates of their spouses, survived attack under the Bill of Rights in the $1974 \mathrm{Ca}$ nard $^{99}$ case. It was contended that equality before the law was denied because non-Indian women were automatically entitled to administer their husband's estates, whereas Indian women could be appointed only if the government official having authority over tribal matters so decided. In both the former case alleging sex discrimination and the latter claiming racial discrimination, the Court discerned no conflict between its holdings there and the decision in Drybones.

The final case, Bliss ${ }^{100}$, decided in 1978 , involved a challenge to the federal Unemployment Insurance Act's pregnancy provisions. It was alleged that the complainant, a pregnant woman, was discriminated against on the basis of sex and denied "equality before the law" because she was refused, on the basis of her pregnancy, benefits granted to non-pregnant workers. The Supreme Court of Canada, relying upon reasoning closely resembling that employed by

97. Id. at 509. The issue raised in Lavell became the subject of an application to the Human Rights Committee of the United Nations pursuant to the Optional Protocol of the International Covenant on Civil and Political Rights. The Committee held that Canada's decision in the Lavell case violated the Covenant. Sandra Lovelace $v$. Canada, U.N. Doc. CCPR/C/DR (XIII) (1981) (communication No. R. 6/24). On the impact of Canada's international human rights obligations upon domestic law, see generally, Claydon, "The Application of International Human Rights Law by Canadian Courts," 30 Buffalo L. Rev. 727 (1981).

98. Santa Clara Pueblo v. Martinez, 436 U.S. 49 (1978).

99. A.G. Can. v. Canard, 52 D.L.R. 3d 548 (1975).

100. Bliss v. A.G. Canada, 92 D.L.R. 3d 417 (1978). For an extended discussion of the issues raised in Bliss, see generally, Gold, supra, n. 90. 
our Supreme Court in similar contexts, concluded that the challenged scheme did not constitute sex discrimination: "Any inequality between the sexes in this area is not created by legislation but by nature."101 In other words, discrimination based upon pregnancy was not sex discrimination. Moreover, no denial of equality before the law occurred because the challenged law did not impose a penalty on one group and not on another, as in the case of Drybones, but rather withheld a benefit.

While each of these post- Drybones decisions has its own intricate rationale, at bottom all reflect the Court's uneasiness with its role of judicial review under the Bill of Rights. ${ }^{102}$ The Court's concern was undoubtedly heightened by the fact that the equal protection challenges in Lavell and Canard threatened the comprehensive scheme for handling Indian matters on reserves established by the Indian Act, a question not presented by Drybones. ${ }^{103}$ Questions that many had thought resolved by Drybones, such as whether the Bill of Rights was "quasi-constitutional"104 or only a canon of construction ${ }^{105}$ and as to the applicability of the "frozen concepts" doctrine $^{106}$ arose anew during the late 1970s. Instead of interpreting

101. Id. at 422. Another formulation used by a lower court judge in Bliss and adopted by the Supreme Court majority was as follows:

If section 46 treats unemployed pregnant women differently from other unemployed persons, be they male or female, it is, it seems to me, because they are pregnant and not because they are women. 77 D.L.R. 3d 609, 613 (1978).

The United States cases on this issue, which reach the same conclusion, are Geduldig v. Aiello, 417 U.S. 484 (1974) (constitutional) and General Electric v. Gilbert, 429 U.S. 125 (1976) (Title VII).

102. One commentator observed as follows:

Though Drybones established the principle that the Bill of Rights can be used to render legislation inoperative, it did not usher in a golden age of $\mathrm{Ca}$ nadian jurisprudence. On the contrary, the Court appeared afraid of the implications of its decision and the post-Drybones decade of litigation under the Bill of Rights was characterized by a marked retrenchment on the part of the Court.

Gold, supra, n. 90 at 353.

103. Eberts, "The Rights of Women," in The Practice of Freedom, supra, n. 41 at 238. Cohen, Due Process of Law 33 (1977).

104. The Canadian Bill of Rights is a half-way house between a purely common law regime and a constitutional one; it may aptly be described as a quasi-constitutional instrument.

Hogan v. The Queen, 2 S.C.R. 574, 597 (1975).

105. Compelling reasons ought to be advanced to justify the Court in this case to employ a statutory (as contrasted with a constitutional) jurisdiction to deny operative effect to a substantive measure duly enacted by Parliament constitutionally competent to do so, and exercising its powers in accordance with the tenets of responsible government, which underlie the discharge of legislative authority under the British North America Act.

Curr v. The Queen, 1972 S.C.R. 889, 899 (describing Bill as creating statutory jurisdiction).

106. Regina v. Miller and Cockriell, 70 D.L.R. 3d 324 (1977) (mandatory death penalty for murder held not to constitute cruel and unusual punishment under Bill of rights since law predated the Bill's coming into force). 
the Bill of Rights in a way that would serve to check encroachments on civil rights, the Court chose rather to perform a judicial function very much like that demanded in federal-provincial ultra-vires disputes, deferring to the plenary power of the Parliament in areas within its competence. A law enacted by Parliament for a "valid federal objective" was, by definition, viewed as consistent with provisions of the Bill of Rights. ${ }^{107}$

\section{The Charter of Rights and Freedoms}

Efforts to amend the British North America Act to include a Bill of Rights which began about 1945 bore fruit on 17 April 1982. On that date, the new Canadian Constitution, ${ }^{108}$ containing a Charter of Rights and Freedoms (a bill of rights), went into force.

When originally submitted by the government of Prime Minister Trudeau, the Charter of Rights and Freedoms envisioned a major departure from the approach employed in the Canadian Bill of Rights of 1960. Not only was the Charter to limit provincial, as well as federal, legislative authority, it was also to provide protections beyond the power of the Parliament or the provincial legislatures to alter, amend or repeal except by way of constitutional amendment. In effect, the principle of parliamentary supremacy would be replaced by that of judicial power to review and declare unconstitutional legislation inconsistent with provisions of the Charter. ${ }^{109}$

107. Regina v. Burnshine, 44 D.L.R. 3d 584 (1974). "Legislation dealing with a particular class of people is valid if it is enacted for the purpose of achieving a valid federal objective." Prata v. Min. of Manpower and Immigration, 52 D.L.R. 3d 383, 387 (1976). Gold emphasizes that the Supreme Court's behavior in this regard can be understood only in the context of the Canadian legal culture, the definitive character of which "is the central place occupied by the principle of the supremacy of Parliament." Supra n. 90 at 349. This principle has had the effect in Canada, as is true of Great Britain, of creating a judiciary that views its role as more that of applying the law rather than performing a lawmaking function, to use Prof. Atiyah's dichotomy. Atiyah, "Lawyers and Rules: Some Anglo-American Comparisons," 37 Sw. L.J. 545-48 (1983).

108. Canada Act 1982, ch. 11. The Charter of Rights and Freedoms comprises $\S \S 1$ 34. The Charter provides civil rights-civil liberties protections against governmental, not private encroachments. See Sec. 32(1) and Hogg, Canada Act 1982 Annotated 7578 (1983). Provisional human rights provisions, insofar as they relate to purely private conduct should not be affected by the Charter.

109. For a full discussion of the development of and debate over this earlier version of the Constitution, see Milne, The New Canadian Constitution (1982); Reference re Amendment of the Constitution of Canada, 125 D.L.R. 3d 1 (1982). See generally, Wildsmith, "Canadian Constitutional Law, The Repatriation Reference and The Constitutional Acts, 1867-1982: An Overview," in MacKay (ed.), The Canadian Charter of Rights Law Practice Revolutionized (1982); and McWhinney, Canada and the Constitution 1979-1982: Patriation and the Charter of Rights (1982). Ironically, perhaps, Canada's problems with bilingualism may have served to propel, rather than retard, the enactment of the Charter. According to one leading commentator:

The major impetus in Canada for a constitutional Bill of Rights is concern for Canadian unity when challenged by cultural dualism. One important reason 
The Charter's provisions are divided into eleven major categories. Three have a direct bearing on the question of racial and other forms of discrimination. The first of these three occupies a category all its own denominated "Equality Rights." 110 In essence, it guarantees equal protection without discrimination, particularly on the basis of race, national or ethnic origin, color, religion, sex, age or mental or physical disability, drawing heavily from similar protections in provincial and federal human rights legislation. But its language can be understood only in light of the difficulties experienced by the Supreme Court of Canada in interpreting the "equality before the law and protection of the law" provision of the Canadian Bill of Rights. ${ }^{111}$

The Court's conclusion in Lavell and Canard was that "equality before the law" meant "equality of treatment in the enforcement and application of the laws of Canada before the law enforcement authorities and the ordinary Courts of the land,"112 not that the laws themselves need treat Indian women and men equally or Indian and non-Indian widows alike in matters of estate administration. The Charter employs, therefore, the language "equal before and under the law" to convey that the laws themselves must treat people nondiscriminatorily. The Court's decision in Bliss held that "equality before the law" did not require that government benefits be granted equally, only that penalties not be imposed discriminatorily. The Charter's response is to guarantee "the right to the equal protection and equal benefit of the law."

why Pierre Trudeau has always insisted on a new Bill of Rights has been his commitment to guarantee language rights to all French Canadians and thereby to defuse the threat of Québecois nationalism. Weiler, "Of Judges and Rights, or Should Canada Have a Constitutional Bill of Rights?" 60 Dalhousie Rev. 205, 207 (1980).

110. Charter of Rights and Freedoms, supra n. 108 (hereinafter cited as Charter), $\S 15$. Sec. 15 reads as follows:

15(1) Every individual is equal before and under the law and has the right to the equal protection and equal benefit of the law without discrimination and, in particular, without discrimination based on race, national or ethnic origin, colour, religion, sex, age or mental or physical disability.

(2) Subsection (1) does not preclude any law, program or activity that has as its object the amelioration of conditions of disadvantaged individuals or groups including those that are disadvantaged because of race, national or ethnic origin, colour, religion, sex, age or mental or physical disability.

111. Hough, "Equality Provisions in the Charter: Their Meaning and Interrelationships with Federal and Provincial Human Rights Acts," in MacKay (ed.), The Cana.dian Charter of Rights Law Practice Revolutionized 319-22 (1982).

112. The Supreme Court of Canada adopted this definition based upon its reading of the classic work on English constitutional law, Dicey, An Introduction to the Study of the Law of the Constitution (10th ed. 1982). This interpretation of Dicey has been severely criticized by Canadian scholars. See, for example, Tarnopolsky, supra n. 81 at $120-24,295-300$. 


\section{Affirmative Action}

Also included in the first category is a provision declaring that the preceding "equal protection" guarantees are not meant to preclude "any law, program or activity designed to ameliorate the conditions of disadvantaged individuals and groups ..." In view of the extent to which human rights legislation has also attempted to encourage affirmative action at both the provincial and federal levels, this provision no longer looks so unusual. ${ }^{113}$ But it bears pointing out that much readier acceptance in Canada of affirmative action concepts than has been true in the United States is likely the result of its history of addressing group, as well as individual, rights. The British North American Act itself was concerned with the rights of minority language and religous groups. ${ }^{114}$ The Charter provides enhanced protections for such groups and directs, furthermore, that all its provisions "be interpreted in a manner consistent with the preservation and enhancement of the multicultural heritage of Canadians." 115 The composition of the Supreme Court of Canada, itself, is affected by group considerations. By statute, at least three of its nine members must be judges from either the courts or bar of Quebec, a requirement that ensures their competence in civil law and fluency in French. ${ }^{116}$

Not only have these differences been recognized and respected-they have formed the basis for programs designed specifically to improve the conditions of disadvantaged groups. In 1963, for example, a federal commission report on the disproportionate absence of Francophonic Canadians in the public service resulted in what one commentator referred to as "the greatest affirmative action program of all" to correct this underrepresentation. A number of such programs to benefit Indians and women have subsequently been approved at both the provincial and federal levels. ${ }^{117}$

Interestingly, the response of the Supreme Court of Canada to the concept of affirmative action has been positive, even though its one decision to date on the issue, the Athabasca Tribal Council case, held a preferential program for Indians without legal authority. The Court rejected, however, arguments that such an affirmative action plan would discriminate against non-Indians in violation of the province's human rights legislation. ${ }^{118}$ The affirmative action provision of the Charter is, therefore, less a response to an unfavorable

113. Eight provinces and the federal government have explicit affirmative action provisions in their human rights laws. Tarnopolsky, supra n. 21 at 146.

114. BNA §§ $93 \& 133$. See discussion, supra n. 10.

115. Charter, $\S 27$.

116. Russell, supra n. 39 at 59-69.

117. Tarnopolsky, supra n. 78 at 434.

118. Supra n. 78. 
judicial climate in Canada than an effort to avoid the controversy that had arisen in the United States, in such cases as Bakke ${ }^{119}$ and Weber, ${ }^{120}$ over "reverse discrimination." 121

\section{Sex Discrimination}

The second provision relevant to this inquiry, in effect an Equal Rights Amendment, declares that "notwithstanding anything in this Charter, the rights and freedoms referred to it are guaranteed equally to male and female persons."122 This section of the Charter was added to the original Trudeau Government proposal in April 1981 in response to criticisms that the "Equality Rights" provisions were not sufficiently strong to ensure against judicial interpretations unfavorable to the rights of women. ${ }^{123}$ As with respect to the matter of racial discrimination, the Supreme Court of Canada's record on women's rights issues has not been very good, even before its decisions in Lavell and Bliss. ${ }^{124}$ In 1928, for example, it was confronted with the question of whether women were "persons" under a provision of the British North America Act which allowed "qualified persons" to serve in the Canadian Senate. The Court concluded they were not, a decision that was subsequently overturned on appeal to the British Privy Council. ${ }^{125}$ The Supreme Court's interpretation of the word "persons," however, followed a long line of English and lower Canadian court opinions barring women from voting, holding public office or training for the professions. ${ }^{126}$

But two more recent considerations were at the heart of those concerned abut the protection of women's rights under the Charter. First, the Supreme Court's deferential treatment of laws challenged

119. University of California Regents .v. Bakke, 438 U.S. 265 (1978).

120. Steelworkers v. Weber, 443 U.S. 193 (1979).

121. The question is once again before the U.S. Supreme Court in the current term. Firefighters Union No. 1784 v. Stotts, No. 82-206, cert. granted, 103 Sup. Ct. 2451 (1983).

122. Charter, § 28. This "Equal Rights Amendment" provision became effective immediately. In contrast, the "Equal Rights" provisions do not take effect until 1985. Charter, $\S 32(2)$. It was thought that this three-year period was needed by the federal and provincial governments to amend those statutes that appeared to violate Sec. 15. See Hogg, "A Comparison of the Canadian Charter of Rights and Freedoms and the Canadian Bill of Rights," in Tarnpolsky and Beaudoin, supra n. 78 at 20-21. During this interim period, provincial human rights legislation, the Canadian Human Rights Act and the Canadian Bill of Rights will remain in force. To the extent that inconsistencies exist between those laws and the Charter, thereafter, the Charter will control. Hogg, in Tarnopolsky and Beaudoin, supra n. 78 at 2-4.

123. Milne, supra n. 109 at 100.

124. See generally, Baines, supra n. 95 at 31-63.

125. Edwards v. A.G. Canada, [1930] A.C. 124.

126. Eberts, "The Rights of Women," in The Practice of Freedom, supra n. 41 at 231-235. One provincial judge even cited the often criticized U.S. Supreme Court decision upholding state denial of bar admission to women, Bradwell v. Illinois, 83 U.S. 130 (1873), to reach a similar result. Re Mabel French, 37 N.B. 359, 371 (1905). 
under the Bill of Rights raised fears that the same type of "minimum scrutiny" would be invoked under the "Equality Rights" provisions of the Charter. ${ }^{127}$ Second, even if the intricate efforts in the drafting of the "Equality Rights" provisions to forestall judicial analysis like that in Lavell and Bliss proved successful, the courts might nevertheless resort to a form of "intermediate scrutiny" adopted by the U.S. Supreme Court in sex discrimination cases. ${ }^{128}$

Ironically perhaps, the provision ultimately included in the Charter on the equal rights of males and females occupies a status more favorable than that afforded other equality rights such as, for example, the prohibition against racial discrimination. First, it is not affected by a potentially limiting introductory provision of the Charter that "guarantees the rights and freedoms set out in it subject only to such reasonable limits prescribed by law as can be demonstrably justified in a free and democratic society."129 Since some commentators have viewed this provision as incorporating the "valid federal objective" test that proved fatal to the challenge in Bliss, its inapplicability to the equal rights amendment provision may have major positive consequences for future sex discrimination litigation. Presumably the more general equality provisions are subject to the "reasonable limits" mode of analysis. ${ }^{130}$

The second reason for the equal rights amendment provision's unique status relates to one of the conditions provincial officials exacted in November 1981 from the Trudeau Government in exchange for their supporting the Charter. The provinces were able to effect an amendment to the Charter giving their legislatures non obstante power with respect to certain of its provisions. ${ }^{131}$ The approved clause, which came to include the Parliament as well, allows the legislatures to override certain provisions of the Charter for a period of five years by way of explicit legislative action. At the end of five years, the overriden provision resumes effect unless a further override is enacted. The "equality of male and female" provision is not subject to this override process, largely as a result of extremely effective lobbying by women's groups at the time of the compromise. But the more general equality provisions having to do with discrimi-

127. "Women, Human Rights \& The Constitution," submission of the Canadian Advisory Council on the Status of Women to the Special Joint Committee on the Constitution (18 November 1980) 2 CHRR C/35 (1981). Eberts, "The Rights of Women," in The Practice of Freedom, supra n. 41 at 235-36.

128. Craig v. Boren, 429 U.S. 190 (1976). Eberts, "Women and Constitutional Renewal," in Doerr \& Carrier, supra, n. 95 at 9-13. Williams, "Sex Discrimination Under the Charter: Some Problems of Theory," 4 CHRR C/83-1 (1983).

129. Charter, § 1. Tarnopolsky, supra, n. 78 at 436-37.

130. Marx, "Entrenchment, Limitations and Non-Obstante," in Tarnopolsky \& Beaudoin supra n. 78 at $61-70$.

131. Milne, supra n. 109 at 149-55. 
nation on the basis of race and national or ethnic origin can be overridden. ${ }^{132}$

Consequently, the special status afforded in the Charter to the "equality of male and female" provision solves certain problems with respect to treatment of sex discrimination but raises a host of others.

\section{Override}

On the other hand, American lawyers should find it strange that there is not general consternation in Canada over the inclusion, at the "Eleventh Hour," of non obstante provisions in a document that was originally designed to "entrench" civil rights and civil liberties against legislative tampering. The central role judicial review has played in our legal system since Marbury $v$. Madison,${ }^{133}$ for all the criticism it has received over the years, ${ }^{134}$ predisposes us to question any scheme that would permit the overturning of constitutional decisions by simple legislation. ${ }^{135}$

Canadian lawyers, in contrast, even those involved in civil rights litigation or scholarship, tend to view the override provisions as being a positive feature of the Charter, at best, and tolerable, at worst. ${ }^{136}$ The reasons for this curious response, by United States standards, can be explained in several ways. First, many Canadian

132. Charter, $\S 33$. There has also been some suggestion that the affirmative action and equal rights provisions of the Charter may be in direct conflict. The prevailing view, however, seems to be that, since the central purpose behind each was the amelioration of conditions for women, they can be read consistently. Tarnopolsky, supra, n. 78 at $436-37$.

133. 5 U.S. (1 Cranch) 137 (1803).

134. Ely, Democracy and Distrust (1980); Perry, The Constitution, the Courts, and Human Rights (1982).

135. See for example the ongoing and heated debate over Congress' power to limit federal court jurisdiction. Redish, Federal Courts 140-148 (1983). Since the new Constitution does not explicitly "entrench" the Supreme Court, leaving it, arguably, subject to Parliamentary legislation, this concern is likely to be exacerbated. The only references to the Supreme Court in the Canada Act 1982 relate to the mode by which the Act may be amended. See $\S \S 41(d)$ and 42(d). Presumably, the substantive provision of the BNA Acts pertaining to the Court, incorporated by reference, would still control. See supra n. 5 and n. 13. See also on this point, Hogg, supra n. 108 at 92-94.

136. For example, the General Counsel of the Canadian Civil Liberties Association stated as follows with respect to the non obstante clause:

Our reaction is one of great relief. They did not emasculate the Charter.

The process is a rather ingenious marriage of a bill of rights and a parliamentary democracy. The result is a strong charter with an escape valve for the legislatures. The "notwithstanding" clause will be a red flag for opposition parties in the press. That will make it politically difflcult for a government to override the Charter. Political difficulty is a reasonable safeguard for the Charter.

Borovoy, quoted in Jeffrey, The Charter of Rights and Freedoms and Its Effect on Canadians at 14 (Library of Parliament, June 1982). Borovoy expressed similar sentiments to me in an interview I conducted on $28 \mathrm{July} 1982$ in Toronto. Hogg, in Tarnopolsky and Beaudoin, supra n. 78 at 10-13. 
lawyers were uncomfortable in principle with the idea of shifting power from the Parliament and provincial legislatures to the courts, as anti-majoritarian and unlikely, in any event, to alter strongly held public attitudes no matter what the courts decided. ${ }^{137}$ Second, as a practical matter, Canada's experience with the protection of civil rights and civil liberties has been, as this article has attempted to recount, a story of judicial ineffectiveness and inhospitality. By comparison, the political branches at both the federal and provincial levels have, at least since the end of World War II, been actively engaged in recognizing and providing protections for individual rights. ${ }^{138}$ And, finally where non obstante clauses have been included in human rights legislation, such provisions have been rarely exercised. The 1960 Canadian Bill of Rights and the human rights laws of three provinces-Alberta, Quebec and Saskatchewan-all contain non obstante provisions. Yet, Parliament has seen fit to invoke the non obstante provision of the Bill of Rights only once in over 23 years. And the provincial legislatures have been similarly sparing in their use of the override power. In at least one instance a provincial attempt to exercise the override power was discontinued in response to strong public opposition. ${ }^{139}$ What the Canadians have done by including the non obstante concept in their Charter,

137. Tarnopolsky, Canada's preeminent authority on civil rights and civil liberties, takes the same position with respect to the non obstante clause in the Charter as he did toward a similar provision in the Bill of Rights. In 1975 he stated as follows:

Although I believe that the Supreme Court should be able to declare legislation inoperative if it is inconsistent with the Bill of Rights, nevertheless I believe that Parliament, cognizant of the fact that in the opinion of the Supreme Court a certain legislative measure is contrary to the Bill of Rights, should be able to decide that the legislation should operate notwithstanding the Bill of Rights. I do not believe that a Supreme Court, even with a written Bill of Rights in the constitution, can ultimately stand in the way of a legislature determined to take certain action. All I ask of the Supreme Court and of a written Bill of Rights is that the legislature be conscious of the fact that an impartial tribunal, whose role it is to interpret and apply the law, has expressed its opinion that certain action is contrary to the Bill of Rights. Moreover, many of the cases which involve values protected by a Bill of Rights concern administrative, and not legislative, acts. Even in the United States, it is not so much Acts of Congress or the state legislatures that have been held invalid, as administrative actions taken pursuant to these Acts. Therefore, in these cases the impediment of parlimentary sovereignty on judicial review is not often at issue.

Quoted in Tarnopolsky, "A Full Overview of the Charter," supra n. 88 at 123. See also, McWhinney, "The Supreme Court and the Bill of Rights-The Lessons of Comparative Jurisprudence," 37 Can. B. Rev. 16 (1959); and Conklin, In Defence of Fundamental Rights 96-122 (1979). For a very interesting discussion of proposals to entrench individual rights in Great Britain, see Fitzgerald, "An English Bill of Rights," $70 \mathrm{Geo}$. L.J. 1229 (1982). For U.S. non obstante parallels, see Calabresi, $A$ Common Law for the Age of Statutes 18, n. 8 (1982).

138. McKay, "Judicial Process in the Supreme Court of Canada: The Patriation Reference and its Implications for the Charter of Rights," 21 Osgoode Hall L.J. 55, 58 60 (1983).

139. Tarnopolsky, supra n. 88 at 121-22. Marx, "Entrenchment, Limitations and 
quite simply, is decide to repose greater trust in their legislatures, rather than in their courts, to protect individual rights.

More specifically, however, the fact that some equality rights are subject to the "reasonable limits" and the non obstante provisions and others are not raises the question of whether such distinctions dictate differential standards of review depending upon the type of discrimination alleged. If the "equality of male and female" provision, given its unique status, dictates the application of a very high level of scrutiny in sex discrimination cases, does that mean that race discrimination claims are entitled to lesser protection? Furthermore, the general "equality rights" provisions specifically list race, national or ethnic origin, color, religion, sex, age or mental or physical disability as examples of prohibited grounds for discrimination and acceptable grounds for affirmative action. Does that mean that laws alleged to discriminate on those grounds will receive stricter scrutiny than legislation challenged on grounds, such as sexual orientation, not explicitly mentioned in the Charter? In other words, will the Charter's structure in this respect necessitate something akin to the U.S. Supreme Court's several-tiered mode of constitutional analysis: strict scrutiny for suspect classifications or legislation affecting fundamental rights; intermediate scrutiny for non-suspect but highly questionable classifications; and minimal scrutiny for other social and economic legislation? ${ }^{140}$

If current United States practice in this respect is consulted, one would have to find that-with the exception of race, national and ethnic origin, color and religion-the other prohibited grounds of discrimination are not viewed as triggering strict scrutiny. And there appears to be no inclination on the part of the Burger Court to expand the list of suspect classifications or fundamental interests. ${ }^{141}$ There is some suggestion in Canadian Bill of Rights jurisprudence, however, that while the legislation reached discrimination on other than the grounds specifically listed, discrimination based on one of the listed grounds, such as race, would be illegal "a fortiori."142 In any event, based upon the Court's Drybones decision and the approach taken by both federal and provincial human rights legislation, it is difficult to believe that classifications based upon race, national or ethnic origin or color will be evaluated other than by the strictest standards. Similarly, the protections provided for religious

Non-Obstante," in Tarnopolsky and Beaudoin, supra n. 78 at 70-74. Marx, "Human Rights and Emergency Powers," in The Practice of Freedom, supra n. 41 at 447.

140. Gunther, supra, n. 70 at 670-75.

141. See, for example, Plyler v. Doe, 457 U.S. 202 (1982) where the Supreme Court declared unconstitutional a Texas statute which denied Mexican illegal alien children a free public education. The Court used an "intermediate scrutiny" approach to reach its result.

142. Curr v. The Queen, 26 D.L.R. 3d 603, 611 (1972). 
freedom in the Charter itself, the 1960 Bill of Rights, the British North America Act and in pre-1960 Supreme Court rulings all point to requiring a high standard of justification for laws alleged to infringe upon that right. It is in the areas of age and mental or physical disability that the "reasonable limits" provision will likely be invoked to justify certain forms of discrimination, particularly in employment. ${ }^{143}$

\section{Sanctions}

The final section of the Charter that must be addressed here relates to the question of how Canadians will go about obtaining remedies for violations of its provisions. That this is not simple, as constitutions go, can be seen from our experience in the United States. Chief Justice John Marshall asserted in 1803 that "the very essence of civil liberty" was, that for every vested legal right there be a remedy. ${ }^{144}$ But it was not until 1971 that the U.S. Supreme Court found an "implied right of action" based upon the Constitution itself to remedy alleged violations by federal officials. ${ }^{145}$ And the current Court has expressed a growing dissatisfaction with that earlier decision, in any event. ${ }^{146}$

The Charter directs itself to this issue of remedy specifically by providing that "anyone whose rights or freedoms . . . have been infringed or denied may apply to a court of competent jurisdiction to obtain such remedy as the court considers appropriate and just in the circumstances."147 Directness however, does not necessarily answer all the problems. Several questions remain.

First, the language of the remedial provision seems to suggest a cutting back on current Canadian doctrines of standing. United States law on standing recognizes the existence of both constitutional ("case or controversy" requirements of Art. III) and prudential limitations, flowing from separation of powers considerations. The Burger court has relied quite heavily on one or the other head of this doctrine to limit federal court resolution of certain disputes, particularly those brought by taxpayers. ${ }^{148}$

In Canada, however, standing is a matter within the courts' dis-

143. Human rights legislation in Canada generally includes "bona fide occupational qualification" (bfoq) exceptions with respect to discrimination on the basis of disability and age in employment. Tarnopolsky, supra n. 21 at 225-27, 304-11.

144. Marbury v. Madison, supra n. 132 at 163.

145. Bivens v. Six Unknown Named Agents, 403 U.S. 388 (1971).

146. Chappell v. Wallace, $103 \mathrm{~S}$. Ct. 2362 (1983) (rejecting application of Bivens to claim by soldier against his superior officer).

147. Charter, $\S 24(1)$. $\S 24(2)$, which addresses the question of exclusion of evidence in criminal proceedings, is not within the scope of this paper.

148. See, for example, Valley Christian Forge College v. Americans United, 454 U.S. 464 (1982). 
cretion. The Supreme Court of Canada has tended to exercise its discretion in favor of, rather than against, granting standing. Perhaps, the most far-reaching case in this regard involved a suit brought by a former provincial official and staunch anti-abortion advocate. ${ }^{149} \mathrm{He}$ sought to challenge provisions of the Criminal Code dealing with abortion on the grounds that they violated the "protection of life" guarantees of the Bill of Rights. Specifically, he attacked those provisions of the Code that exempted from criminal sanctions certain types of abortion. The Supreme Court granted him standing. The Charter's emphasis upon granting relief to persons whose rights "have been infringed" would appear to exclude, however, plaintiffs with only a "genuine interest as a citizen in the validity of the legislation," 150 like the anti-abortion advocate.

The same language poses another problem, for it does not make clear whether one may seek a remedy for an anticipatory breach of Charter provisions. Since it speaks of rights that "have been infringed or denied," there is the suggestion that a breach must already have occurred. Earlier drafts of this provision, however, and the general availability of declaratory relief against the government in Canada suggest that remedies for impending infringements can be sought. ${ }^{151}$

One last consideration has to do with whether injunctive relief will be considered by the courts as a remedy "appropriate and just in the circumstances" of some disputes. There are at least two diffculties in this respect. The first is that, in the absence of statute, injunctions are not available against federal or provincial governments. But it appears that injunctions may, under certain cir-

149. Min. of Justice (Can.) v. Borowski, 130 D.L.R. 3d 588 (1982).

150. . . . [T] o establish status as a plaintiff in a suit seeking a declaration that legislation is invalid, if there is a serious issue as to its invalidity, a person need only to show that he is affected by it directly or that he has a genuine interest as a citizen in the validity of the legislation and that there is no other reasonable and effective manner in which the issue may be brought before the Court.

Id., at 606. On the other hand, it may well be that another part of the Canada Act will allow broader standing in declaratory judgment cases. Sec. 52(1) declares the Constitution of Canada "the supreme law of Canada" and any law inconsistent with it "of no force and effect." This section could be read to allow a Borowski plaintiff to seek a declaration of unconstitutionality. If he or she wanted other forms of relief, however, the requirements of $\S 24(1)$ would have to be met. See generally, Gibson, "Enforcement of the Canadian Charter of Rights and Freedoms (Sec. 24)," in Tarnopolsky and Beaudoin, supra n. 78 at 493-97; and Beckton, "The Future Impact of the Charter of Rights and Freedoms on the Canadian Legal Profession," in Law Practice Revolutionized, supra n. 109 at $135-38$.

151. Gibson, supra n. 78 at 498-500; Ewaschuk, "The Charter of Rights, An Overview and Remedies," in Continuing Legal Education Seminar, supra n. 88 at 63-70. Manning, Rights, Freedoms and the Courts 466-81 (1983). See Quebec Association of Protestant School Boards v. A.G. Quebec, 140 D.L.R. 33 (3d) (1982) for an early, yet thoughtful, opinion holding declaratory relief available under $\$ 24(1)$ of the Charter. 
cumstances, be granted against government officials. ${ }^{152}$ This may, as a practical matter, constitute adequate relief. More problematic, however, is the reluctance of Canadian courts to grant mandatory, as opposed to prohibitory, injunctions. ${ }^{153}$ Our success in the United States in dealing with racial discrimination has depended quite heavily on the ability of federal courts to grant such relief. ${ }^{154}$

\section{CONCLUSION}

As the foregoing has established, I hope, the history of civil rights in Canada has turned very much on the inability or unwillingness of its courts to act vigorously on behalf of individual liberties. Each step along the way-the development of provincial and federal human rights laws, the 1960 Bill of Rights and now the Charter-has represented an effort to strike a proper balance between the principles of legislative supremacy and judicial review. Let us hope that Canada has found the right formula at last.

152. Declaratory relief appears to be the preferred remedy sought against public officials, rather than an injunction. Ewaschuk, supra n. 137 at 75-76; Hogg, Liability of the Crown 18-28 (1971); Hanbury \& Maudsley, Modern Equity 88 (11th ed. 1981). The rule that allows Canadians to obtain injunctive relief against government officials but not against the Crown closely parallels United States Eleventh Amendment Doctrine: The states are immune to such suits in federal court but their officers are not, in general. Ex Parte Young, 209 U.S. 123 (1908).

153. Hanbury, id. at 722-724.

154. Fiss, The Civil Rights Injunction (1978). 